\title{
Review: Domestic herbivores and food security: current contribution, trends and challenges for a sustainable development
}

\author{
A. Mottet ${ }^{\dagger}$, F. Teillard, P. Boettcher, G. De' Besi and B. Besbes \\ Animal Production and Health Division, Food and Agriculture Organization, Viale delle Terme di Caracalla, 00153 Rome, Italy
}

(Received 10 January 2018; Accepted 26 July 2018; First published online 14 September 2018)

\begin{abstract}
Herbivores are found in a variety of ecosystems all over the world. Permanent pastures and meadows cover about $25 \%$ of global land. We currently count one domesticated herbivore for two people in the world and the number is growing. Production systems and products are highly diverse. This high diversity is the result of thousands of years of natural selection and human-controlled breeding, as well as migration and trade. Because of the high diversity of domestic herbivore genetic resources, herders have been able to live in regions where no alternative for income generation exists. Meat and milk from domestic herbivores provide $16 \%$ and $8 \%$ of the global protein and kilocalorie consumption, respectively. They also provide a variety of essential micronutrients but can contribute to overweight and obesity when consumed in excess. Domestic herbivores also make significant contribution to food security through the production of manure, draught power and transport and the generation of income at household and national level. They have a key role to play in women's empowerment and gender equality, both in rural and urban areas.

Demand for meat and milk is increasing because of population growth, rising incomes and urbanisation. This trend is expected to continue, especially in Latin America, South Asia and China. The sustainable development of domestic herbivore production needs to address the feed/food and the efficiency of herbivores in turning forages into protein. It also needs to address the contribution of herbivores to greenhouse gas emissions, especially of ruminants through enteric fermentation, and their mitigation potential, including through carbon sequestration. Animal genetic resources have a key role to play in mitigating and adapting to climate change. The role of ruminants in the circular bioeconomy needs to be enhanced, promoting the use of by-products and waste as livestock feed and the recycling of manure for energy and nutrients. Finally, the role of domestic herbivores in providing secure livelihoods and economic opportunities for millions of smallholder farmers and pastoralists needs to be enhanced. The sustainable development of the sector therefore requires adequate policies, and there are already a variety of mechanisms available, including regulations, cross-compliance systems, payments for environmental services and research and development. Priority areas for policy makers should be aligned with the global framework of the Sustainable Development Goals and include: (i) food security and nutrition, (ii) economic development and livelihoods, (iii) animal and human health and finally, (iv) environment, climate and natural resources.
\end{abstract}

Keywords: ruminants, sustainable development, environment, meat and milk, policies

\section{Implications}

This paper reviews the different ways domestic herbivores contribute to global food security while paying particular attention to the diversity of production systems and environments. It identifies the challenges for the sector to continue to respond to the growing demand for meat and milk in a sustainable way, including the livelihoods of small holders, trade in animal products, climate change and environmental negative externalities. The issues discussed in this paper are

\footnotetext{
${ }^{\dagger}$ E-mail: anne.mottet@fao.org
}

not only of economic, environmental and social relevance to scientists but also of policy makers, civil society and the private sector.

\section{Introduction}

Pastures and rangelands cover about $25 \%$ of global land and two-thirds of global agricultural land. Herbivores such as bison, antelopes, deer, llamas, camels and giraffes but also cattle, buffalo, sheep and goats, horses and donkeys are found in grassland ecosystems all over the world. Since the origin of agriculture, 10000 years ago, people have 
domesticated and kept herbivores for their capacity to turn marginal resources into high value food, produce manure for fertilization, generate fibre and leather and provide essential services, such as animal traction.

The world already counts about 1.4 billion cattle, 2.1 billion sheep and goats and about 350 million other domestic herbivores. Overall, this represents more than one domestic herbivores for two humans on the planet. They are large users of land, water and nutrients and contribute signi ficantly to greenhouse gas (GHG) emissions, especially through enteric fermentation from ruminant species. Because demand for animal products is increasing as a result of population growth, rising incomes and urbanisation, the role of domestic herbivores in achieving food security in a sustainable way is being discussed.

Most domestic herbivores are ruminants, that is cattle, buffalo, sheep and goat, and this review will therefore have a particular focus on ruminants. As summarized by Gerber et al. (2015), the specificity of ruminant production, when looking at its contribution to human livelihood and interactions with the environment, is deeply rooted in the biology of ruminants. The authors singled out three features: digestion (the ability to turn cellulose and other organic fibre into protein with different levels of efficiency), reproduction (with fertility and prolificacy rates that are lower than monogastric species, especially for cattle) and diversity (with ruminant breeds outnumbering avian breeds or pig breeds, reflecting their adaptation to their environment). Because of these specific features, ruminants contribute to food security and nutrition through a vast diversity of products but also services, such as animal traction and manure. This paper aims to provide a global overview of domestic herbivores production systems (with particular focus on ruminants given their share in global meat and milk production from herbivores), their diversity, their contribution to food security, the trends in the sector, the challenges and policy options for sustainable development.

\section{Domestic herbivores production systems and products are highly diverse}

Domestic herbivores are very diverse and encompass many species. In this review, the focus is put on ruminants, which represent the bulk of domestic herbivores, but information is provided about non-ruminant animals, such as camelids, horses or donkeys, when available.

Ruminants can be found in very different types of ecosystems, from marginal natural grasslands in dry or cold conditions such as the steppes of Siberia and Patagonia or mountainous conditions (alpine pastures of Europe, the Andes, Himalaya or the Rocky Mountains) to temperate, semi-arid or arid environments, ranging from lowlands and great plains to tropical savannahs and drylands. Although marginal grasslands are usually natural in arid or polar areas, which means that herbaceous vegetation corresponds to the local biome, temperate and semi-arid grasslands can either be natural, semi-natural or cultivated.

Ruminants can be classified in many typologies, responding to different aims. Factors to consider in order to characterise this diversity include the main purpose of the herd, the type of feed, of orientation and housing. At global level, three main types of ruminant production systems can be considered, adapted from Sere and Steinfeld (1996): grazing, mixed crop-livestock production and feedlots.

\section{Animal genetic diversity}

Cattle and buffalo breeds represent $25 \%$ of the world's 5584 recorded mammalian livestock breeds and sheep breeds constitute a similar proportion, followed by horses and goats, with $15 \%$ and $11 \%$, respectively (Food and Agriculture Organization (FAO), 2015). By comparison, only 2543 avian breeds and a bit more than 560 pig breeds are reported. The very high diversity of domestic herbivores, observed today, is the result of hundreds or thousands of years of natural selection and human-controlled breeding, as well as migration and trade in contrasted agro-ecological conditions where animals adapted, evolved and developed. Textbook examples of this process are the Latin American Zebu and Criollo cattle. These breeds originated from far different genetic and geographic backgrounds (from South Asia and southwest Europe, respectively) but are now uniquely adapted to the conditions where they are found.

Adaptation of breeds to changing environments and demands is a response to selection for specific characteristics that are needed for the animals to survive, and for herders to sustain their livelihoods, such as tolerance to droughts or harsh environments, resistance to diseases or yields and body conformation. Thanks to the high diversity of herbivore genetic resources, and ruminants in particular, herders have been able to live in regions where no alternative for income generation exists, especially from crops or other animal species. They have also managed to develop breeds with the high levels of productivity through cross-breeding and selection where agro-ecological conditions are more favourable.

However, some ruminant breeds are also found throughout the world, such as the cattle Holstein breed, as a result of agricultural specialisation and concentration. The genetic diversity of domestic herbivores is threatened. Risks identified include indiscriminate cross-breeding but also economic drivers and changing market demands, weaknesses in management programmes, policies and institutions, degradation of natural resources (or problems with access to such resources), climate change and disease epidemics (FAO, 2015).

Conservation of animal genetic diversity has become a priority. The Global Plan of Action for Animal Genetic Resources (FAO, 2007), which includes 23 strategic priorities for action and improved management, was therefore 
developed and adopted by member countries of the Food and Agriculture Organization of the United Nations.

\section{Domestic herbivores are and will be key to food security and nutrition}

Contribution to food production and nutritional benefits Meat and milk from domestic herbivores provide $16 \%$ of the global protein consumption and $8 \%$ of the global energy consumption (Table 1). Most of the meat and milk from domestic herbivores is produced by cattle, with $20 \%$ of meat and $83 \%$ of milk. In comparison, buffaloes produce $1 \%$ of global meat production and $13 \%$ of milk. Small ruminants have a smaller contribution, with $5 \%$ of meat and $4 \%$ of milk.

Mixed crop-livestock production systems have the largest contribution to milk and meat production in all four species of ruminants: $59 \%, 85 \%$ and $57 \%$ for cattle, buffalo and small ruminants (sheep and goats), respectively (Table 2). The rest of production comes from grazing systems, and to a lower extent from feedlots in the case of cattle. Although animals in feedlots have high growth rates and heavy carcasses, they are not widespread and their total contribution to protein production from cattle remains low $(5 \%)$.
Meat and milk also make an important contribution to food security and nutrition through the provision of a variety of micronutrients - for example vitamin $A$, vitamin $B_{12}$, riboflavin, calcium, iron and zinc (Table 3 ) - that can be locally difficult to obtain or assimilate in adequate quantities from plant-source foods alone (Murphy \& Allen, 2003; Randolph et al., 2007). This is particularly true for vulnerable population groups that only have access to monotonous diets lacking nutrient-dense foods (Allen, 2013). For example, meat and milk provide easily absorbable iron, zinc, calcium and vitamin $A$, and are the only dietary source for vitamin $B_{12}$. They are the protein source with the highest density of threonine and lysine, which are in relatively short supply in most plant-based foods, and present high levels of sulphur containing amino acids. These nutrients are necessary for immune function, cognitive development, growth, etc. Therefore, nutrient-rich foods such as meat and milk are particularly important during the first 1000 days of life and for pregnant and lactating women.

Health considerations need to be balanced with the consumption of meat and milk (FAO, in prep.). Only one-third of the world's adult population produces lactase, an enzyme that enables processing of the lactose in the milk. In some regions, such as Southern Africa or South-East Asia, the presence of this enzyme is particularly low (Curry, 2013),

Table 1 Number of domestic herbivores and contribution to global food production (source: FAOSTAT, 2017)

\begin{tabular}{|c|c|c|c|c|c|}
\hline & $\begin{array}{l}\text { Heads } \\
\text { (millions) }\end{array}$ & $\begin{array}{l}\% \text { of global meat } \\
\text { production* }\end{array}$ & $\begin{array}{l}\% \text { of global milk } \\
\text { production** }\end{array}$ & $\begin{array}{l}\% \text { of global kcal } \\
\text { consumption }\end{array}$ & $\begin{array}{l}\% \text { of global protein } \\
\text { consumption }\end{array}$ \\
\hline Cattle & 1474.5 & 20.3 & 82.6 & \multirow{5}{*}{8} & \multirow{5}{*}{16} \\
\hline Buffaloes & 194.5 & 1.2 & 13.4 & & \\
\hline Goats & 1011.3 & 1.7 & 2.3 & & \\
\hline Sheep & 1195.6 & 2.7 & 1.3 & & \\
\hline Camels & 27.7 & 0.2 & 0.4 & & \\
\hline Other camelids & 8.9 & 0.01 & - & - & - \\
\hline Horses & 58.8 & 0.3 & - & - & - \\
\hline Asses & 42.8 & 0.1 & - & - & - \\
\hline Mules & 10.2 & 0.02 & - & - & - \\
\hline
\end{tabular}

*313 million tonnes.

${ }^{* *} 765$ million tonnes.

Table 2 Number of ruminants and contribution to global food production, by production systems (source: Global Livestock Environmental Assessment Model - GLEAM 2.0 (available at www.fao.org/gleam)

\begin{tabular}{|c|c|c|c|c|c|}
\hline Species & $\begin{array}{l}\text { Production } \\
\text { systems }\end{array}$ & $\begin{array}{l}\text { Heads } \\
\text { (millions) }\end{array}$ & $\begin{array}{c}\text { Production } \\
\text { (tonnes of proteins) }\end{array}$ & $\begin{array}{l}\% \text { of protein production } \\
\text { by specie }\end{array}$ & $\begin{array}{l}\% \text { of global protein } \\
\text { consumption }\end{array}$ \\
\hline \multirow[t]{3}{*}{ Cattle } & Grazing & 508.8 & 10338175 & 35 & 5.1 \\
\hline & Mixed & 906.4 & 17306165 & 59 & 8.5 \\
\hline & Feedlots & 55.3 & 1518764 & 5 & 0.7 \\
\hline \multirow[t]{2}{*}{ Buffaloes } & Grazing & 36.4 & 584321 & 15 & 0.3 \\
\hline & Mixed & 160.7 & 3403574 & 85 & 1.7 \\
\hline \multirow[t]{2}{*}{ Small ruminants } & Grazing & 925.7 & 1224623 & 43 & 0.6 \\
\hline & Mixed & 1167.1 & 1656386 & 57 & 0.8 \\
\hline
\end{tabular}


Table 3 Comparison of nutrient content of meat, milk and eggs; relative amount/kcal (Allen, 2013)

\begin{tabular}{lcccccccc}
\hline \hline & Heme iron & Total iron & Zinc & Vitamin A & Riboflavin & Vitamin B 12 & Folate & Calcium \\
\hline Meat & +++ & +++ & +++ & + & ++ & +++ & + & + \\
Milk & 0 & + & + & ++ & +++ & ++ & +++ & +++ \\
Eggs & 0 & + & + & +++ & ++ & ++ & + & 0 \\
\hline \hline
\end{tabular}

0, no content; + , low content; ++ , intermediate content; +++ , high content.

though milk consumption in these regions remain lower than levels at which lactose intolerance becomes a health issue. With the ongoing changes in lifestyles, including dietary patterns and sedentary behaviours, and the surge of noncommunicable diseases, focus has also been given to health risks associated with the overconsumption of meat, especially processed, in modern Western-pattern diets, and to recommend moderate consumption of animal fats, especially saturated fats.

\section{Growth in demand and contrasted trends \\ by systems and regions}

The number of domestic herbivores is growing at a rate of about $1 \%$ a year. Demand for animal-source foods is increasing because of population growth, rising incomes and urbanisation (FA0, 2009). In the 1961-2007 period, the average annual consumption growth rate has been estimated to be $1.5 \%$ for bovine meat and $1.7 \%$ for sheep meat. Growth rates have been higher for pig meat (3.1\%) and poultry (5.1\%). Developing countries accounted for a vast majority of the global meat consumption growth, with an overall annual growth rate of $4.9 \%$. The largest consumption increases have occurred in East Asia, but mostly driven by non-herbivores (pig and poultry), and in the Near East and North Africa region with an annual growth of $6.5 \%$ and $4.3 \%$, respectively (Alexandratos and Bruinsma, 2012).

Similar trends have been recorded in consumption of milk and milk products. The annual consumption growth rate over the past five decades has been $1.4 \%$ at the global level and $3.5 \%$ in developing countries. The regions that have experienced the highest expansion in the consumption of milk and milk products have been East and South Asia, with an annual growth of $5.9 \%$ and $4.0 \%$, respectively (Alexandratos and Bruinsma, 2012).

In order to respond to the growing demand for livestock products, a number of developing countries have rapidly increased their livestock outputs, especially from the 1980s onwards. The global meat production growth was possible due to significant increases in livestock numbers but also to productivity growths. The latter have been observed in some ruminant production systems but have been particularly high in monogastrics, that is poultry and pigs. For example, although the global number of slaughtered cattle and buffaloes increased by $62 \%$ between 1965 and 2005, the average carcass weight only improved by $28 \%$ on the same period, according to FAOSTAT. When looking at milked cows, their number doubled in the same period but the average global milk yield per cow only improved by $10 \%$. The contribution of large and small ruminants to meat production growth has been limited (FA0, 2013).

Today, pigs and chickens contribute to about $68 \%$ of global meat production. Cattle production accounts for a considerably larger portion of the global meat produced than small ruminants $(20 \%$ v. $5 \%)$. The largest beef producers are the United States of America, Brazil, China and Argentina. Small ruminant production plays a key role in the Near East and North Africa, sub-Saharan Africa and South Asia.

In the past four decades, world milk production has increased by more than 50\%, from 522 million tonnes in 1986 to 798 million tonnes in 2016. Most of the expansion in milk production has been in South Asia (particularly India), which is the main driver of milk production growth in the developing world. This growth is mostly the result of an increase in the numbers of producing animals rather than a rise in productivity per head. Milk and milk products account for about $14 \%$ of global agricultural trade. Many developing countries are increasingly dependent on imports of dairy products (mainly from developed countries) because the domestic supply does not meet the growing demand (FAO, 2013; FAOSTAT, 2017).

The global human population is estimated to reach 9.6 billion in 2050, with about $70 \%$ living in urban areas, whereas incomes are expected to increase by $2 \%$ a year. As a consequence, the growth of the livestock sector is expected to continue in the coming decades, with developing countries accounting for the bulk of the additional output. According to the projections of Alexandratos and Bruinsma (2012), between 2005 and 2050 poultry will continue to drive the expansion in global meat production but bovine and sheep meat production will also significantly increase (66\% and $92 \%$, respectively). The same projections showed that the production of milk and milk products will increase by $62 \%$ over the same period. The organisation for economic co-operation and development (OECD)/FAO outlook report (2017) also projects an increase in meat production over the next decade (largely driven by a growth in poultry meat production). In the 2016-26 period, both cattle and sheep meat production are expected to increase but sheep meat will register the strongest growth $(21 \%)$, with an expected global growth rate of $2.0 \%$ per annum. Three quarters of the additional beef production is expected to be produced in Argentina, China, Brazil, India, Mexico and Pakistan. Most of the growth in sheep meat production $(40 \%)$ is projected to occur in China, which is already the largest producing country. Milk production is also expected to show an increasing trend in the coming decade. Compared to the 
2014-16 base period, milk production is expected to increase by 178 million tonnes (22\%). Over $77 \%$ of the additional milk production is attributed to developing countries, particularly India and Pakistan.

\section{Production of manure, draught power and transport}

Through manure, domestic herbivores return part of the nutrients they ingest to soils and contribute to fertility and crop productivity. Bouwman et al. (2013) estimated that total nutrients from livestock manure (including nonherbivore species) exceed nutrients from synthetic fertilizers at global level. However, globally, livestock manure supplies only about $12 \%$ of gross nitrogen input for cropping and up to $23 \%$ in mixed crop-livestock systems in developing countries (Liu et al., 2010). Although part of this discrepancy is explained by the deposition of manure on pastures and rangeland, it also means that more livestock manure could potentially be used for crop fertilization. In Europe, the share of manure in total nitrogen inputs was estimated at 38\% overall and up to $61 \%$ in the Netherlands (Eurostat statistics database, 2018).

Non-ruminant herbivores, such as horses and donkeys, can significantly contribute to income-generating activities and to supporting the livelihoods of the families who own them. They play a critical role in field work (e.g. ploughing, harrowing, seeding and weeding), but also for transport of people, goods, materials and water. In many rural societies, working animals were found to have a particularly important role in the lives of women, by supporting them to fulfil many of their household and income-generating activities, for example transport of water, manure and feed for other livestock (FAO, 2014a; Valette, 2014). In the pastoralist Sahel, donkeys very often accompany herders and livestock in transhumance and are the first resource for transporting water over long distances from boreholes to camps. The population of working equids is increasing in countries like Burkina Faso, Senegal, Mali, Mauritania and Ethiopia. It is expected that the population of working equids will continue to gradually increase in most African countries and potentially increase in some regions of Asia and Latin America (Pritchard, 2010).

\section{Generation of income at households and national level}

The World Bank estimates that 900 million people live on less than US\$1.9/day. About half of them depend fully on farm animals (including non-herbivore species) for their livelihoods: to poor people, farm animals are a major asset representing both capital and, in many cases, a source of income. They can be sold in times of crisis and thus act as household insurance. On the farm, animals provide fertilizer from manure in addition to meat and milk (Mottet \& Tempio, 2017). Therefore, they can contribute to three major pathways out of poverty by: (1) increasing resilience, (2) improving smallholder productivity and (3) increasing market participation (International Livestock Research Institute (ILRI), 2002). There is an extensive evidence of the contribution of ruminants to poverty reduction (de Haan et al.,
2001; Heffernan, 2004; Upton, 2004). For example, in Zambia, nearly one in two household owns ruminants (2014 Zambian Rural Agricultural Livelihood Survey). Livestock income (including monogastrics) accounts for only $13 \%$ of the agricultural income but households owning livestock have higher total income on average (Arslan et al., 2018). This could be explained by the sales of animal products but also the addition of animal traction and manure. Furthermore, livestock diversification is observed in areas where the long-term variation in rainfall is higher and tends to buffer income variability, suggesting that households use livestock diversification as an ex-ante risk management strategy (Teillard et al., 2017).

\section{Women's empowerment and gender equality}

Some two-thirds of poor livestock keepers are estimated to be women (FAO, 2012). They are largely involved in caring for small ruminants and dairy cows in particular (FAO, 2011). But these statistics may underestimate their role. That is because women are less likely than men to define their activities as work, especially with small ruminants, and less likely to report themselves as engaged in livestock management - while working, on average, longer hours than men.

Despite women's important role in animal production and marketing, they have less access to and control over resources, land and capital in particular (FAO, 2009). For example, a gender assessment of the dairy value chain in Kenya found that women contributed most of the labour in traditional and small-scale intensive production systems but often did not own the dairy cows, did not have adequate representation in leadership and decision-making and did not have the same access as men to resources and opportunities (Katothya, 2017). In order to help achieve women's empowerment and gender equality in agricultural populations, priority should be given to improving the conditions of women working in the livestock sector (FAO-AGAL, 2016).

\section{Feed/food competition and feed use efficiencies}

A particularity of domestic herbivores, and ruminants in particular, compared with other livestock species lies in their ability to convert grass, forages and other human-inedible feedstuffs into edible protein. Ruminants-feed rations are composed of a diversity of materials; some, however, are used or produced in concurrence with human edible food. Figure 1 shows the estimated composition of the global feed ration of ruminants. Broken down, $4.3 \%$ of the global dry matter (DM) intake is from cereal grains, which represent a total of 216 million tonnes, or $9 \%$ of global cereal production. When adding soybean meal, about $5 \%$ of the global ruminant feed ration can be potentially considered as directly in competition with human food, a very smaller share than in the case of monogastrics (83\%).

The efficiency with which ruminants convert feed into protein is often criticized compared with monogatrics, poultry in particular. On the animal-to-animal level, this efficiency 


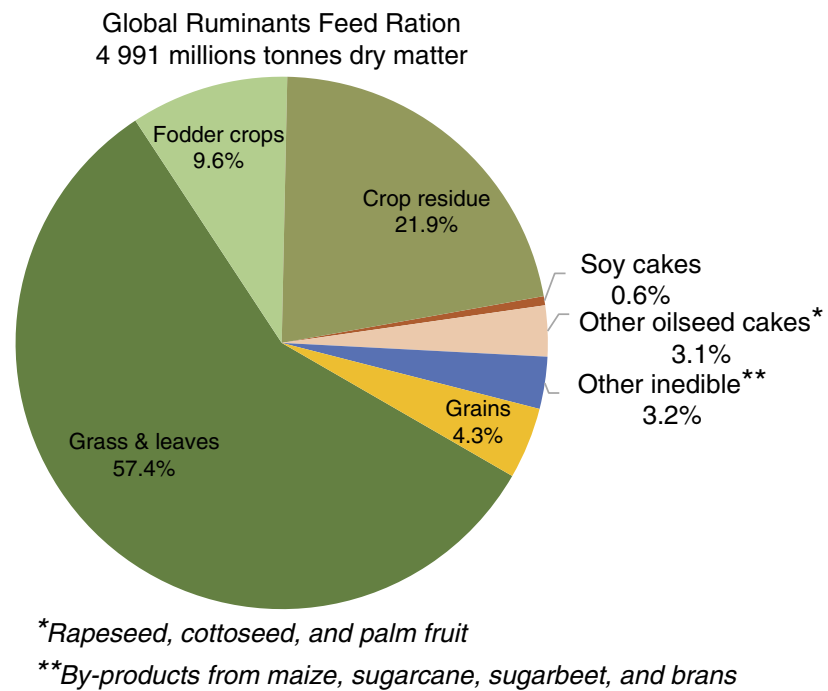

Figure 1 Global ruminant feed ration.

Table 4 Global feed conversion ratios (FCR) from (Mottet et al., 2017)

\begin{tabular}{|c|c|c|c|c|c|c|}
\hline & Protein & FCR 1 & FCR 2 & $\begin{array}{l}\text { Meat } \\
\text { FCR } 2\end{array}$ & FCR 3 & $\begin{array}{c}\text { Protein } \\
\text { FCR } 2\end{array}$ \\
\hline & $\begin{array}{l}\mathrm{Mt} / \\
\text { year }\end{array}$ & $\begin{array}{c}\mathrm{kg} \mathrm{DM} \\
/ \mathrm{kg} \\
\text { protein }\end{array}$ & $\begin{array}{c}\mathrm{kg} \\
\text { edible } \\
\text { DM/kg } \\
\text { protein }\end{array}$ & $\begin{array}{c}\mathrm{kg} \\
\text { edible } \\
\mathrm{DM} / \mathrm{kg} \\
\text { meat }\end{array}$ & $\begin{array}{c}\mathrm{kg} \\
\text { compete } \\
\mathrm{DM} / \mathrm{kg} \\
\text { protein }\end{array}$ & $\begin{array}{c}\text { kg edible } \\
\text { protein/kg } \\
\text { protein }\end{array}$ \\
\hline Ruminants & 36355 & 133 & 6 & 2.8 & 6.7 & 0.6 \\
\hline Monogastrics & 38246 & 30 & 16 & 3.2 & 20.3 & 2.0 \\
\hline All & 74601 & 80 & 12 & 3.1 & 13.7 & 1.3 \\
\hline
\end{tabular}

$\mathrm{FCR} 1=\mathrm{kg}$ of dry matter (DM) intake/kg of protein in the products (meat, milk and eggs); FCR2 = kg of human-edible DM intake/kg of protein in the products; $\mathrm{FCR} 3=\mathrm{kg}$ of DM intake from human-edible feed and soybean cakes $/ \mathrm{kg}$ of protein in the products.

is primarily driven by (i) the quality of the feed and (ii) animal performance (e.g. growth rates, influenced by genetics and health conditions). Though less important, two additional factors can influence feed-use efficiency on the herd or country-wide level: (iii) proportion of meat supplied from the dairy herd, as maintenance energy is diluted over the two products, meat and milk, and (iv) proportion of nonproductive breeding stock in the herd (these animals need to be fed but do not contribute directly to the edible product output). Mottet et al. (2017) estimated that ruminants require an average of $133 \mathrm{~kg} \mathrm{DM} / \mathrm{kg}$ protein produced compared with $30 \mathrm{~kg}$ for monogatsrics (Table 4). However, when considering human-edible DM only, conversion ratios decrease to $6 \mathrm{~kg} \mathrm{DM} / \mathrm{kg}$ protein for ruminants and $16 \mathrm{~kg} \mathrm{DM} /$ $\mathrm{kg}$ protein for monogastrics. More specifically, ruminants need $0.6 \mathrm{~kg}$ of human-edible protein feed intake to produce $1 \mathrm{~kg}$ of protein (contrary to $2 \mathrm{~kg}$ for monogastrics), which makes them net contributors to global human-edible protein production. This ratio diminishes to $0.2 \mathrm{~kg}$ for grazing cattle in non-OECD countries and can be as high as $5.2 \mathrm{~kg}$ for industrial broilers in $\mathrm{OECD}$ countries.
The feed/food competition also lies in the fact that ruminant feed is potentially produced on land where human food could be produced. Domestic herbivores use the larger share of total agricultural land. Mottet et al. (2017) estimate that the total area used by ruminant herbivores reaches 2.3 billion ha, which represent about $45 \%$ of the total agricultural area. In all, $85 \%$ of this area correspond to pastures and grasslands, whereas fodder crops and cereal grains account for $3 \%$ each. The area allocated to soybean cakes based on their respective mass and value compared with the entire soy plant accounts for $1 \%$ of the total (or 32 million ha). Similarly, the area allocated to crop residues reaches 122 million ha or $5 \%$ of the total. Using a methodology based on the yield gap and using as threshold $25 \%$ ratio of actual/potential yield, which corresponds to grasslands having a suitability for crop production ranked by IIASA/FAO (2012) as 'marginal', the same authors estimated that 684.9 million ha of the grasslands used by livestock could be converted to cropland. That is equivalent to $14 \%$ of global agricultural land and half of global arable land, whereas the remaining 1.3 billion ha of pastures and rangelands can be considered non-convertible.

Feed/food competition can be reduced by enhancing the role of domestic herbivores in food systems, which means improving their use of marginal lands and their contribution to turning by-products and crop residues into edible goods, but also to increasing crop productivity.

\section{Environmental sustainability in the context of climate change and sector's growth}

Grazing has a number of ecological functions and roles, including biomass removal that fosters regrowth by preventing the accumulation of dead material, prevention of wild fires, regulation of hydrology and water quality by producing diverse landscapes, conservation of rich grasslands biodiversity and pollinators, dispersal of seeds through ingestion and release in dung, but also of organic matter and nutrients.

\section{Greenhouse gas emissions and climate variability}

Pastures and rangelands are estimated to contain globally between 538 and 871 billion tonnes of carbon, a range similar to the one of carbon stocks in forests (Lal, 2004).

Domestic herbivores, and ruminants in particular, can play a key role in climate change mitigation and adaptation. The livestock sector is a significant contributor to global humaninduced GHG emissions, with an estimated total of 8.1 gigatonnes $\mathrm{CO}_{2}$-eq emitted in $2010^{1}$, an estimate based on a life cycle assessment accounting for all GHG sources in the supply chains, on farm, but also upstream (e.g. feed production) and downstream (processing and transport). In total, $79 \%$ of the sector's emissions come from ruminants (62\% from cattle), largely due to methane emissions

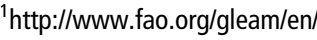


resulting from enteric fermentation. Enteric methane emissions represent $30 \%$ of global methane emissions. There is also a strong potential for reducing emissions. Gerber et al. (2013) estimated that a 30\% reduction in GHG emissions is possible if all producers adopted the technologies and practices currently used by the $25 \%$ most efficient producers. This reduction varies between production species and ranges from $41 \%$ for buffaloes to $27 \%$ for beef cattle, whereas dairy cattle and small ruminants were all between $30 \%$ and $36 \%$. By looking at feasible interventions in different production systems, Mottet et al. (2016) showed mitigation potentials ranging from $14 \%$ to $41 \%$ according to species, systems and regions.

Although practices improving productivity are key to mitigating GHG emissions from ruminants, direct mitigation technologies also exist, though they present different levels of development. Inhibitors targeting microbes in the rumen that produce enteric methane, such as nitrates of lipid acids, have proven to be efficient both in vitro and on farm trials. Some commercial inhibitors are already marketed. Technologies such as vaccines to stimulate the production of antibodies against methanogens or transfers of microbiomes from low methane animals are also being investigated. The main limitation to wider adoption once pilot studies are implemented is the cost of such technologies, though regulations may also play a role.

The importance of livestock for GHG emissions mitigation is now well recognized by countries, 92 developing countries have included livestock in their nationally determined contributions under the Paris Climate Agreement. In addition, during the 23rd Conference of the Parties to the United Nations Framework Convention on Climate Change, all member countries adopted the 'Koronivia joint work on agriculture', a decision requesting work on issues related to agriculture, with a specific focus on livestock.

Three important ways exist to substantially reduce emissions from ruminant production. The first one is to reduce emission intensity (i.e. emissions per unit of product) through productivity improvements. This can be achieved with improved feed quality (e.g. improved grassland management, feed processing and strategic use of supplements), animal health and husbandry (reducing the incidence and impact of diseases and improving reproductive efficiency) and breeding (improving traits such as weight gain, milk yield or fertility). A multi-stakeholder approach in the dairy sector in Kenya showed that these improvements could decrease methane emission intensity by $7 \%$ to $45 \%$ whereas improving milk productivity by $4 \%$ to $80 \%$, depending on the intervention and production system assessed (FAO, 2017). The second one is carbon sequestration. The growth in the number of herbivores as well as poor grazing management have led to overgrazing and to the degradation of about $20 \%$ of grassland around the world. There is a high potential for carbon sequestration and productivity recovery through grassland restoration, which can be achieved by adjusting grazing pressure in space and time, better nutrient management and the integration of species (legumes and trees).
The third one is a better integration of ruminants in the circular bioeconomy, by enhancing the use of by-products and crop residues as feed, which also reduces feed/food competition, and by recycling energy and nutrients from manure. This is further developed in a later section.

Ruminants can be used as a tool for climate change adaptation. Managing their mobility, destocking and their ability to consume diverse feed resources and to mobilize body reserves can increase the resilience of food production in a changing climate. De Haan et al. (2016) quantified the contribution of ruminants to resilience in the drylands of subSaharan Africa by combining a participative approach with modelling of biomass availability under various climate scenarios, ruminant population dynamics and feed requirements. They showed that ruminant production is more stable than biomass production, especially under drought scenarios, that is climate-driven variability can be buffered by management practices such as animal movements, adjustments in feed baskets, health interventions and early animal offtake. Ruminants can thus be a significant asset for adaptation, especially in pastoral systems which are much vulnerable to climate change. Similar results have been found in Zambia, where Teillard et al. (2017) showed that livestock production could not only buffer biomass availability under climate change but also increase economic resilience at household level.

Role of animal genetic resources in mitigating and adapting to climate change and for other ecosystem services

The diversity of animal genetic resources is particularly important with regard to providing landscape maintenance and other related ecosystem services. Although all herbivorous livestock by their nature are able to graze, variability exists among species (e.g. Glimp 1988) and breeds (e.g. Osoro et al., 2007; Prendiville et al., 2010) in grazing habits. Breeds that are native to a given production environment have adapted in concert with that environment and are thus more likely to play a beneficial role in maintaining the associated landscape. For example, differences in diet selection among breeds may have an impact on weed control by grazing animals, if locally adapted breeds are more willing to consume the undesirable species (Martinez Correal, 2007).

Genetic diversity is also important in the context of climate change. Regarding adaptation, maintaining a wide variety of species and breeds ensures the availability of greater option for breeders should they need to change their animal genetic resources in response to climate change (Boettcher et al., 2015). Genetic diversity is also important with regard to climate change mitigation. Methane emission by ruminant livestock has been found to be under partial genetic control and thus genetic selection is available as an option for intervention (Pickering et al., 2015). Whether this is best approached by direct selection to decrease emissions or indirect selection by improving efficiency is a question open for debate, but will rely on the 
continued maintenance of sufficient within-breed genetic variation.

\section{Nutrient use and the role of domestic herbivores in bioeconomy and in agroecosystems management} Livestock production, herbivores and monogastrics, has a large impact on nutrient cycles and it is a significant contributor to nutrient losses into air, water and soil, which lead to negative environmental impacts including climate change and eutrophication (Galloway et al., 2010; Sutton et al., 2013). At the same time, livestock can be a tool to promote circular bioeconomy, that is to minimize energy and nutrient leaks in food systems by recycling by-products or waste as inputs to the production cycle. Better integrating ruminants into the circular bioeconomy can be achieved by increasing the share of products that are non-edible by human in ruminants' diets, such as grass, agro-industrial by-products and food waste, and by using the animals to recycle nutrients (manure) and energy (animal traction, biogas). Crop residues and agro-industrial by-products such as bran, molasses or oilseed cakes already represent nearly $26 \%$ of the total ruminant feed intake. They will be produced in larger amounts as the human population grows and consumes ever more processed food, and could become an environmental burden. Ruminants, but also monogastrics, play a critical role in adding value to these products. Food waste represents about one-third of all food produced for human consumption and represents a missed opportunity to improve the global food productivity and to mitigate the environmental impacts (FAO, 2013). Though this potential is higher for pigs, which are omnivorous, with the right regulatory frameworks (related to public health in particular), ruminants can also be used to recover nutrients from waste. For example, in Japan, $52 \%$ of waste from the food industry is now used as livestock feed.

\section{Policies in support of sustainable livestock development, including domestic herbivores}

\section{Existing policy mechanisms}

Policies aiming to support directly agricultural production can be found in all countries and have been often criticized for their potential negative externalities when their focus is only on increasing outputs. For example, the Farmer Input Support Programme in Zambia subsidizing maize seeds and synthetic fertilizer has had limited impact on yields and has been used more by larger farmers, thus not reducing inequalities (Mason et al., 2013). It has also resulted in lower crop-livestock integration at farm level and manure application.

Policy mechanisms addressing the different dimensions of sustainability already exist for the livestock sector. In various regions, mechanisms such as regulations, subsidies, taxes or market interventions have been implemented for over two decades to reduce the negative impact of livestock production on the environment. A good example lies in the European Union directive on nitrates which constrains livestock farmers to ensure storage capacity for manure to avoid discharges in the environment and to apply the manure in specific periods of time to avoid leaching (Directive 1991/676/EC). Regulations supporting greater integration of livestock with other sectors can also address environmental and economic objectives at the same time. In Japan, the 52\% of waste from the food industry used as livestock feed is a result of revised recycling laws including targets for private companies and a certification system.

More generally, policy schemes providing support to productions can be linked to a requirement to meet certain environmental targets, which is known as cross-compliance. This type of policy falls into the principle of 'polluter pays, provider gets'.

Payments for environmental services (PES), such as improved water quality or quantity, biodiversity conservation or carbon sequestration, offer a way of simultaneously addressing environmental goals and combatting poverty (Steinfeld et al., 2006). Payments for environmental services are often seen as a market solution for environmental problems, in practice, they depend strongly on state and/or community engagement. Vatn (2010) explained that public action was indeed needed because rights to the land that delivers the service must be clarified and because transaction costs for environmental services are very high, which means that buyers are often public bodies. Successful examples of PES exist but barriers to wider adoption lie first in the fact that it is difficult to put a price on natural resources, even when they have a value to the community. Vatn (2010) cited the example of water for Andean communities in Bolivia, which is a public good rather than a merchandise. As PES may create further inequities between producers, careful conditions of applications should be foreseen. Silvestri et al. (2012) provide examples of emerging and operational PES in livestock inclusive agricultural production systems, including for climate regulation, watershed management and hydrological services and biodiversity conservation.

Other policy mechanisms aim at improving knowledge and information sharing and include extension services to farmers, research and development to identify and disseminate best practices. Commonly used approaches for dissemination include communication, training, demonstration farms and networks to facilitate linkages among sector stakeholders. A good example of a research initiative at a global level is the global research alliance on agricultural GHG, which focuses on the research and development of technologies and practices to increase food production without increasing emissions. Research efforts are organized across different agricultural subsectors, and include a livestock research group that aims to find solutions to reduce the GHG emissions intensity and increase the quantity of soil carbon stored in grazing lands. However, policy makers need to consider the constraints faced by farmers, especially in developing countries. The transfer of practices and technologies through the use of extension is much more likely to be effective for commercial farmers than for subsistence farmers, who will 
often be unable to obtain the same economic returns from adoption (Jack, 2011).

Governments may also choose to use taxes on trade as a policy mechanism, for example taxing imports using environmental criteria or animal welfare, or on the contrary, by not taxing specific inputs or equipment to favour their use. However, because of implications with the World Trade Organization (see for example the EU ban on hormone beef), public standards such as the Hazard Analysis and Critical Control Points system or the organic food label are preferred (Hobbs, 2010). Private standards, such as those developed by retailers, are also quite common in OECD countries.

\section{Global framework and areas of policy needs}

Environmental impacts of the livestock sector or its economic development need to be considered in the broader scope of sustainability and in an integrated way with other agricultural production and economic sectors. Food and Agriculture Organization has developed five principles for sustainable food and agriculture: efficiency; conservation of resources; livelihoods and social equity; resilience; and governance (FAO, 2014b). These principles are at the core of FAO's strategy to support countries achieving Zero Hunger, the second Sustainable Development Goal of the UN2030 Agenda. This Agenda constitutes an integrated, indivisible set of global priorities for sustainable development. It is accepted by all countries and applicable to all. The 17 goals and their targets integrate social, economic and environmental aspects and recognize their interlinkages in achieving sustainable development in all its dimensions. The UN2030 Agenda is the framework with which countries can plan their policies for sustainable livestock development. Recognizing the role of the sector in achieving the UN2030 Agenda, ministers of agriculture from 69 nations met with scientific experts, representatives of the sector and non-governmental organisations during the 2018 Global Forum for Food and Agriculture in Berlin. In total, four areas of work were identified for livestock: food and nutrition security; livelihoods and economic growth; health and animal welfare; and climate and natural resource use. These areas of work constitute the priorities in policy needs for livestock.

With regard to food and nutrition security, the wide diversity of diets needs to be considered and the adequate levels of consumptions of animal products for a healthy diet need to be promoted. Reducing feed/food competition by encouraging recycling is also a priority. Herbivores have a particular role to play given their ability to use the abundant sources of non-edible forages such as grass and crop residues.

To enhance the role of livestock in livelihoods and economic growth, efficiency and productivity gains should continue with focus on best husbandry and feed practices and adequate management of animal genetic resources. Special attention shall be given to market access for small holders and pastoralists, whereas uncontrolled and poorly regulated growth of intensive and large-scale production units needs to be cut.
In the area of animal health and animal welfare, in relation to human health, One Health approaches should be promoted. In particular, the use of antimicrobials should be cut by improving husbandry practices and prevention of animal diseases. Regulatory bodies need to be strengthen, in particular for the control of transboundary diseases. Animal welfare should be made a priority in all development programmes as means to improve animal husbandry and health.

Finally, in the area of natural resources, climate and the environment, the production and consumption of low carbon animal products should be encouraged, and the reduction of GHG emissions should be a priority, as well as carbon storage in pastures (e.g. restoration of degraded pastures). A better integration of livestock, and domestic herbivores in particular, in the circular bioeconomy can increase natural resource use efficiency.

Integrated approaches can already be found. For example, a number of World Bank investments in livestock at country level now estimate ex-ante their impact on GHG emissions in addition to productivity or even include the reduction of emissions as an objective. Another example is one of the recent World Bank US\$248 million investment in pastoralism in the Sahel, which integrates components on animal health, natural resource management, facilitation of market access and crisis management. Initiatives supporting the participation of producer's organisations or civil society, such as the Pastoralist Knowledge Hub, are key in the implementation of such programmes.

Achieving the sustainable development goals depends on global partnerships that mobilize and share knowledge, expertise, technology and financial resources. This is recognized by the UN 2030 Agenda in its Goal 17: Partnerships for the Goals. Thus, the success of the Agenda 2030 and the successful implementation of its Sustainable Development Goals will depend on the establishment of multi-stakeholder partnerships, such as the Global Agenda for Sustainable Livestock.

\section{Conclusions}

Demand for animal products will continue to grow while we need to address the triple burden of malnutrition, which are food insecurity, undernutrition and overweight and obesity. A particular challenge to the sustainable development of herbivorous production, and particularly ruminant, is the existence of multiple trade-offs between environmental interactions, as previously highlighted by other authors (e.g. Gerber, 2015). This is further complicated by the large range of other sustainability challenges such as public health (including diets, food safety and antimicrobial resistance), food security, social equity, economic growth and animal welfare.

Similarly to what Mottet \& Tempio (2017) concluded for poultry, domestic herbivores can respond to the growing demand for meat and milk and enhance their contribution to food security and nutrition. But to achieve this objective in a sustainable way, we need to consider their role beyond just 
providing food. We need to produce more with less, while benefiting all. Herbivores have a key role in providing secure livelihoods and economic opportunities for millions of smallholder farmers and other economically disadvantaged people. Enhancing this role requires adequate policies, including for improved market access and land tenure. We also need to ensure that domestic herbivores use natural resources efficiently, and that they contribute to mitigate and adapt to climate change and reduce other environmental impacts. Conservation of animal genetic resources has a key role to play in achieving these objectives. Finally, it is necessary that the sector enhances human, animal and environmental health and welfare. Existing policy mechanisms to support sustainable herbivore production include regulations to limit negative externalities, subsidies and taxes, cross-compliance systems, PES and knowledge and information sharing, for example through research, development and extension. These policies need to be designed in a holistic manner to best reconcile the various demands concerning productivity, sustainability and societal values. They should be tailored to regional/national contexts but should be aligned with global frameworks. In particular, the UN2030 Agenda and its 17 Sustainable Development Goals provide an integrated framework for policy makers, in which all priority areas identified for herbivores find a place and can be articulated to avoid trade-offs between goals and enhance synergies.

Policies should not only consider the goods and services provided by the different production systems, their contribution to the economy and their environmental impacts but also producers' capacity to react and invest, the cost associated with dissemination, extension and monitoring change and the different entry points for public policies in the different production systems. Given the complexity of the challenges and the diversity of actors involved, multistakeholder initiatives are key to this process.

\section{Acknowledgements}

The authors would like to thank the staff of the FAO's Animal Production and Health division whose work has largely contributed to this manuscript as well as two anonymous reviewers and the journal's editors who have provided very valuable comments.

\section{Declaration of interest}

No conflict of interest was identified.

\section{Ethics statement}

None.

\section{Software and data repository resources}

None of the data were deposited in an official repository.

\section{References}

Alexandratos N and Bruinsma J 2012. World agriculture towards 2030/2050: the 2012 revision, volume 12, no. 3. ESA Working paper. FAO, Rome, Italy.
Allen L 2013. Comparing the value of protein sources for maternal and child nutrition. Food and Nutrition Bulletin 34, 263-266.

Arslan A, Asfaw S, Cavatassi R, Lipper L, McCarthy N, Kokwe M and Phiri G 2018. Diversification as part of a CSA strategy: the cases of Zambia and Malawi. In Climate smart agriculture. Natural resource management and policy (ed. L Lipper, N McCarthy, D Zilberman, S Asfaw and G Branca), volume 52. Springer, Cham, Switzerland.

Boettcher PJ, Hoffmann I, Baumung R, Drucker AG, McManus C, Berg P, Stella A Nilsen LB, Moran D, Naves M and Thompson MC 2015. Genetic resources and genomics for adaptation of livestock to climate change. Frontiers in Genetics 5, 461.

Bouwman L, Goldewijk KK, Van Der Hoek KW, Beusen AH, Van Vuuren DP, Willems J, Rufino MC and Stehfest E 2013. Exploring global changes in nitrogen and phosphorus cycles in agriculture induced by livestock production over the 1900-2050 period. Proceedings of the National Academy of Sciences 110, 20882-20887.

Curry A. 2013. The milk revolution. Nature 500, 20-22.

De Haan C, Cervigni R, Mottet A, Conchedda G, Gerber P, Msangi S, Lesnoff M, Ham $F$ and Nigussie $K$ 2016. Vulnerability and resilience in livestock systems in the drylands of Sub-Saharan Africa. In Prospects for livestock-based livelihoods in africa's drylands (ed. C de Haan), The World Bank, Washington, DC, USA.

De Haan C, Schillhorn van Veen T, Brandenburg B, Gauthier J, Le Gall F, Mearns R and Simeon M 2001. Livestock development: implications for rural poverty, the environment and global food security. The World Bank, Washington, DC, USA.

Directive 1991/676/EC. 1991. Council directive of 12 December 1991 concerning the protection of waters against pollution caused by nitrates from agricultural sources. Official Journal of the European Communities 375, 1-8.

Eurostat statistics database 2018. European Commission, Belgium, Brussels.

FAO-AGAL 2016. Synthesis - Livestock and the Sustainable Development Goals. Retrieved from http://www.livestockdialogue.org/fileadmin/templates/res_livestock/docs/2016/Panama/FA0-AGAL_synthesis_Panama_Livestock_and_SDGs. pdf.

FAOSTAT 2017. FAOSTAT statistics database. FAO, Rome, Italy.

Food and Agriculture Organization and New Zealand Agricultural Greenhouse Gas Research Centre 2017. Options for low emission development in the Kenya dairy sector - reducing enteric methane for food security and livelihoods. FAO, Rome, Italy.

Food and Agriculture Organization 2007. Global Plan of Action for Animal Genetic 153 Resources. FAO, Rome, Italy.

Food and Agriculture Organization 2009. The state of food and agriculture Livestock in the balance. FAO, Rome, Italy.

Food and Agriculture Organization 2011. The state of food and agriculture 2010-2011. Women in agriculture: closing the gender gap for development. FA0, Rome, Italy.

Food and Agriculture Organization 2012. Invisible guardians - women manage livestock diversity. FAO Animal Production and Health, paper No. 174. FAO, Rome, Italy.

Food and Agriculture Organization 2013. Food wastage footprint. Impact on natural resources. FAO, Rome, Italy.

Food and Agriculture Organization 2014a. The role, impact and welfare of working (traction and transport) animals. Animal Production and Health Report. No. 5. FAO, Rome, Italy.

Food and Agriculture Organization 2014b. Building a common vision for sustainable food and agriculture. FAO, Rome, Italy.

Food and Agriculture Organization 2015. The second report on The State of the World's Animal Genetic Resources for Food and Agriculture. FAO, Rome, Italy.

Food and Agriculture Organization in prep. Harnessing the potential of livestock to improve the nutrition of vulnerable populations. Technical guidance for programme planning. FAO, Rome, Italy.

Galloway J, Dentener F, Burke M, Dumont E, Bouwman AF, Kohn RA, Mooney $H A$, Seitzinger $S$ and Kroeze C 2010. The impact of animal production systems on the nitrogen cycle. Livestock in a Changing Landscape 1, 83-96.

Gerber PJ, Mottet A, Opio Cl, Falcucci A and Teillard F 2015. Environmental impacts of beef production: review of challenges and perspectives for durability. Meat science 109, 2-12.

Gerber P, Steinfeld H, Henderson B, Mottet A, Opio C, Dijkman J, Falcucci A and Tempio G 2013. Tackling climate change through livestock: a global assessment of emissions and mitigation opportunities. FAO, Rome, Italy. 
Glimp HA 1988. Multi-species grazing and marketing. Rangelands 10, 275-278. Hobbs JE 2010. Public and private standards for food safety and quality: international trade implications. The Estey Centre Journal of International Law and Trade Policy 11, 136.

International Livestock Research Institute 2002. Livestock - a pathway out of poverty. ILRI's strategy to 2010. 24pp. ILRI, Nairobi, Kenya.

Jack BK 2011. Constraints on the adoption of agricultural technologies in developing countries. White paper, Agricultural Technology Adoption Initiative, J-PAL (MIT) and CEGA (UC Berkeley).

Katothya $G$ 2017. Gender assessment of dairy value chains: evidence from Kenya. FAO, Rome, Italy.

Liu J, You L, Amini M, Obersteiner M, Herrero M, Zehnder AJ and Yang H 2010. A high-resolution assessment on global nitrogen flows in cropland. Proceedings of the National Academy of Sciences 107, 8035-8040.

Mason NM, Jayne TS and Mofya-Mukuka R 2013. Zambia's input subsidy programs. Agricultural Economics 44, 613-628.

Martinez Correal G 2007. Jalémosle al criollo (VI). Carta Fedegan 103, 90-91. Murphy SP and Allen LH 2003. Nutritional importance of animal source foods. Journal of Nutrition 133, 3932S-3935S.

Heffernan C 2004. Livestock and the poor: issues in poverty focused livestock development. In Responding to the livestock revolution: the role of globalisation and implications for poverty alleviation (ed. E Owen, T Smith, M Steele, S Anderson, A Duncan, M Herrero, JD Leaver, CK Reynolds, JI Richards and JC Ku-vera), Nottingham University Press, Nottingham, UK.

Lal R 2004. Soil carbon sequestration to mitigate climate change. Geoderma 123, 1-22.

Mottet A, de Haan C, Falcucci A, Tempio G, Opio C and Gerber P 2017. Livestock: on our plates or eating at our table? A new analysis of the feed/ food debate. Global Food Security 14, 1-18.

Mottet A, Henderson B, Opio C, Falcucci A, Tempio G, Silvestri S, Chesterman S and Gerber PJ 2016. Climate change mitigation and productivity gains in livestock supply chains: insights from regional case studies. Regional Environmental Change 17, 129-141.

Mottet A and Tempio $\mathrm{G}$ 2017. Global poultry production: current state and future outlook and challenges. World's Poultry Science Journal 73, 245-256.

Osoro K, García U, Jáuregui BM, Ferreira LM, Rook AJ and Celaya R 2007. Diet selection and live-weight changes of two breeds of goats grazing on heathlands. Animal 1, 449-457.
Pickering NK, Oddy VH, Basarab J, Cammack K, Hayes B, Hegarty RS, Lassen J, McEwan JC, Miller S, Pinares-Patiño CS and de Haas Y 2015. Animal board invited review: genetic possibilities to reduce enteric methane emissions from ruminants. Animal 9, 1431-1440.

Prendiville $R$, Lewis $E$, Pierce KM and Buckley F 2010. Comparative grazing behavior of lactating Holstein-Friesian, Jersey, and Jersey $\mathrm{x}$ Holstein-Friesian dairy cows and its association with intake capacity and production efficiency. Journal of Dairy Science 93, 764-774.

Pritchard J 2010. Animal traction and transport in the 21st century: getting the priorities right. The Veterinary Journal 186, 271-274.

Randolph TF, Schelling E, Grace D, Nicholson CF, Leroy JL, Cole DC and Ruel M 2007. Role of livestock in human nutrition and health for poverty reduction in developing countries. Journal of Animal Science 85, 2788-2800.

Sere C and Steinfeld S 1996. World livestock production systems. Current status, issues and trends. FAO, Rome, Italy.

Silvestri S, Osano P, Leeuw JD, Herrero M, Ericksen P, Kariuki J, Njuki J and Notenbaert A 2012. Greening livestock: assessing the potential of payment for environmental services in livestock inclusive agricultural production systems in developing countries. International Livestock Research Institute, Nairobi, Kenya.

Steinfeld H, Gerber P, Wassenaar TD, Castel V and De Haan C 2006. Livestock's long shadow: environmental issues and options. FAO, Rome, Italy.

Sutton MA, Bleeker A, Howard CM, Bekunda M, Grizzetti B, De Vries W, Van Grinsven HJ, Abrol YP, Adhya TK, Billen G and Davidson EA 2013. Our nutrient world: the challenge to produce more food and energy with less pollution. Centre for Ecology and Hydrology (CEH), Edinburgh, UK.

Teillard F, Mottet A and Alfani F 2017. The role of livestock in adapting to climate change and building economic resilience in Zambia. In Proceedings of the 5th Global Science Conference on Climate Smart Agriculture, Johannesburg, South Africa.

Upton M 2004. The role of livestock in economic development and poverty reduction. Pro-poor livestock policy initiative working paper 10. FAO, Rome, Italy.

Valette D 2014. Invisible helpers. Women's views on the contributions of working donkeys, horses and mules to their lives: key findings from research in Ethiopia, Kenya, India and Pakistan. Voices from women International Report. The Brooke, London, UK.

Vatn A 2010. An institutional analysis of payments for environmental services. Ecological Economics 69, 1245-1252. 